\title{
ANALISA PENGARUH AXIAL FORCE DAN ROTATIONAL SPEED PADA PROSES REPAIR AXLE SHAFT BEKAS MENGGUNAKAN FRICTION WELDING TERHADAP KETANGGUHAN AXLE SHAFT
}

\author{
Irfan Malik Hartanto, Akhmad Hafizh Ainur Rasyid \\ Teknik Mesin, Fakultas Teknik, Universitas Negeri Surabaya \\ 1irfanhartanto@mhs.unesa.ac.id \\ 2akhmadrasyid@unesa.ac.id
}

\begin{abstract}
Abstrak - Semakin meningkatnya pertumbuhan truk dan banyaknya fenomena kegagalan pada komponen Axle Shaft. Berimplikasi pada peningkatan limbah poros yang mengalami kegagalan sehingga dibutuhkan sebuah usaha untuk mengurangi hal tersebut. Salah satu metode pengendalian limbah yang dapat digunakan adalah prinsip repair. Repair merupakan pemeliharaan maupun perbaikan limbah yang masih dapat digunakan untuk fungsi yang sama ataupun fungsi lainnya dengan usaha - usaha tertentu. Metode repair yang dilakukan pada penelitian ini adalah proses penyambungan material menggunakan proses las gesek (friction welding). Melihat fenomena di atas peneliti ingin mengetahui pengaruh kecepatan putar (Rotational Speed) dan gaya tekan aksial (Axial force) terhadap dan ketangguhan pada daerah pengelasan limbah poros Axle Shaft. Metode penelitian ini menggunakan metode eksperimental research dengan proses pengelasan dilakukan pada mesin bubut yang telah ditambahkan alat penekan hidrolik sebagai mekanisme penekanan aksial. Pengujian impact menggunakan metode pengujian impact charphy dengan bentuk spesimen sesuai dengan standar ASTM dengan penletakan takikan berada di daerah base metal, weld metal dan heat effected zone Hasil penelitian menunjukkan kekuatan impact terbesar terdapat pada variasi kecepatan putar $1010 \mathrm{Rpm}$ dengan hasil tertinggi $0.065030 \mathrm{~J} / \mathrm{mm}^{2} \mathrm{pada}$ tekanan tempa $40 \mathrm{Kg} / \mathrm{cm}^{2}$ pada daerah weld metal sedangkan hasil uji impact terendah dihasilkan dari variasi kecepatan putar $1800 \mathrm{Rpm}$ yaitu $0.040970 \mathrm{~J} / \mathrm{mm}^{2}$ pada tekanan tempa $20 \mathrm{Kg} / \mathrm{cm}^{2}$ pada daerah weld metal. Dengan demikian dapat disimpulkan bahwa kecepatan putar (rotational speed) dan tekanan aksial berpengaruh terhadap kekuatan impact hasil pengelasan gesek.
\end{abstract}

Kata Kunci-Kegagalan Komponen; Repair Axle Shaft; Friction Welding; Kecepatan Putar: Tekanan Tempa; Ketangguhan Material .

\begin{abstract}
Increasing truck growth and a large number of failure phenomena on Axle Shaft components. Implied by an increase in shaft waste that fails, so an effort is needed to reduce it. One of the waste control methods that can be used is the repair principle. Repair is the maintenance and repair of waste that can still be used for the same function or other functions with certain businesses. The repair method carried out in this study is the process of joining the material using the friction welding process. Seeing the above phenomenon the researcher wants to know the effect of rotational speed and axial force on and toughness in the axle shaft shaft welding area. This research method uses an experimental research method with a welding process carried out on a lathe that has been added a hydraulic pressure device as an axial suppression mechanism. Impact testing uses charphy impact testing method with specimen shape according to ASTM standard with notch placement in the base metal, weld metal and heat effected zone areaThe results showed the greatest impact strength was found in variations of rotational speed of $1010 \mathrm{Rpm}$ with the highest yield of $0.065030 \mathrm{~J} / \mathrm{mm}^{2}$ at forging pressures of $40 \mathrm{Kg} / \mathrm{cm} 2$ in weld metal areas while the lowest impact test results were generated from variations of $1800 \mathrm{Rpm}$ rotational speed of 0.040970 $\mathrm{J} / \mathrm{mm}^{2}$ at forging pressure $20 \mathrm{Kg} / \mathrm{cm} 2$ in the weld metal area. So it can be concluded that rotational speed and axial pressure affect the impact strength of friction welding results.
\end{abstract}

Kata Kunci-Failure Component; Repair Axle Shaft; Frictionwelding; Rotational Speed; Axial Force; Material Toughness.

\section{PENDAHULUAN}

Kendaraan merupakan salah satu alat transportasi yang banyak digunakan manusia untuk memenuhi kebutuhannya. Perkembangan transportasi dan teknologi transportasi pada era globalisasi berkembang sangat pesat, hal ini ditunjukkan dengan permintaan dan pertumbuhan alat transportasi manusia maupun barang yang mengalami peningkatan setiap tahunnya. Namun pertumbuhan truk yang meningkat setiap tahun, masih belum dibarengi dengan peningkatan kualitas jalan dan regulasi yang menjadi instrumen penting dalam jalannya proses transportasi Hal ini ditunjukkan oleh banyaknya fenomena kegagalan dalam komponen kendaraan truk yang banyak disebabkan oleh faktor tersebut, sehingga menyebabkan kerugian-kerugian material maupun non material.
Melihat pertumbuhan dan fenomena kegagalan pada komponen Rear Wheel yaitu patahnya poros roda belakang kendaraan (Axle Shaft), ditambah beberapa faktor penyebab kegagalan pada poros yang sulit dieliminasi, berimplikasi pada peningkatan limbah poros yang telah mengalami kegagalan. Dengan demikian dibutuhkan sebuah usaha untuk mengurangi hal tersebut. Repair merupakan salah satu prinsip dari prinsip pengelolaan limbah 4R (Recycle, Reuse, Reduce dan Repair), dimana Repair merupakan pemeliharaan maupun perbaikan limbah yang masih dapat digunakan untuk fungsi yang sama ataupun fungsi lainnya dengan usaha - usaha tertentu. 
Metode perbaikan (repair) poros yang digunakan adalah proses penyambungan menggunakan pengelasan gesek (friction welding), Pengelasan gesek merupakan pengelasan yang memanfaatkan energi panas yang timbul dari gesekan dan gaya penekanan pada kedua permukaan yang akan disambung, Keuntungan friction welding yaitu pengelasan dilakukan pada posisi center line, tidak menggunakan bahan tambah dan hasil merata pada seluruh permukaan.

Pada proses pengelasan gesek (friction welding) ini terdapat beberapa parameter yang dapat mempengaruhi kemampuan hasil pengelasan dikutip dari panduan pengelasan (American Welding Society) AWS C6 Recommended Practice for friction welding point 5.6 parameter pengelasan gesek (Friction Welding) yang paling berpengaruh diantaranya adalah Preweld Time, Axial Force, Rotational Speed.

Dikutip dari hasil penelitian sebelumnya, Wahyu Nugroho (2010) pada penelitiannya Pengaruh durasi gesekan, tekanan gesek dan tekanan tempa terhadap kekuatan sambungan las gesek langsung pada baja karbon aisi 1045 yang menyimpulkan bahwa pengaruh dari parameter tekanan gesek, tekanan tempa dan durasi gesekan dapat diketahui pada sifat mekanik dan struktur mikro.

Poedji Haryanto (2011) dalam penelitiannya pengaruh gaya tekan, kecepatan putar, dan waktu kontak pada pengelasan gesek baja ST60 terhadap kualitas sambungan las yang menyimpulkan bahwa struktur mikro pada sambungan terjadi pemadatan struktur dibandingkan diluar sambungan, hal ini menunjukkan peningkatan kekuatan pada daerah sambungan.

Donny Audinandra, Haris Kusnaini, Eko Nurcahyo dan Dimas Angga (2011) pada penelitianya rancang bangun mesin Friction Welding yang menghasilkan produk as sepeda motor dan menbandingkan dengan produk tempa manual yang menyimpulkan bahwa efek waktu gesekan pada pengelasan menghasilkan distribusi kekerasan dan kekuatan tarik yang bervariasi.

Dicky Satyadianto (2015) dengan penelitiannya pengaruh variasi tekanan gesek, tekanan tempa dan durasi gesek terhadap kekuatan impact pada sambungan las gesek (friction welding) dengan menggunakan baja paduan aisi 4140 yang menyimpulkan Dari ketiga parameter yang di variasikan, parameter tekanan gesek paling berpengaruh terhadap kekuatan impact sambungan las direct friction welding.

Muhammad Faisal Dkk (2018) Analisis Kekuatan Tarik pada Logam Axle Shaft dengan Pengelasan Gesek (Friction Welding). Melihat fenomena tersebut peneliti ingin mengetahui pengaruh kecepatan putar (Rotational Speed) dan gaya tekan aksial (Axial force) terhadap ketangguhan pada daerah pengelasan limbah poros Axle Shaft.

\section{METODE}

Metode pendekatan yang dilakukan adalah penelitian analisis eksperimen (experimental research) yang bertujuan untuk mengetahui pengaruh rotational speed $1010 \mathrm{Rpm}, 1800$ Rpm dan axial force $20 \mathrm{Kg} / \mathrm{cm}^{2}, 30 \mathrm{Kg} / \mathrm{cm}^{2}$ dan $40 \mathrm{Kg} / \mathrm{cm}^{2}$ pada proses repair poros menggunakan friction welding terhadap ketangguhan rear axle shaft. Dengan demikian dapat

Irfan Malik Hartanto: Analisa Pengaruh Axial Force ... dibandingkan kekuatan poros rear axle shaft utuh dan rear axle shaft yang telah mengalami rekondisi pada ukuran specimen

Dalam penelitian ini proses pengelasan dilakukan di Laboratorium Permesinan Universitas Negeri Surabaya, proses pengelasan dilakukan di mesin bubut yang telah di tambahkan penekan hidrolik pada posisi kepala lepas sebagai mekanisme penekanan aksial.



a) skema hidrolik

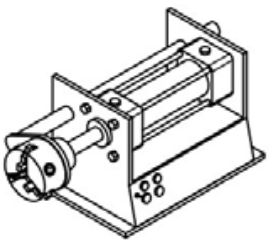

b) penekan hidrolik
Gambar 1 Penekan Aksial (Axial Force)

Alat penekan aksial ini dirancang dengan mekanisme hidrolik karena dengan mekanisme penekanan hidrolik ini penekanan dapat terukur presisi melalui pressure gauge. Alat penekan aksial ini mampu memberi tekanan aksial hingga tekanan maksimal $50 \mathrm{Mpa}$.

Objek penelitian yang digunakan dalam penelitian ini yaitu limbah rear axle shaft truk merk Colt dengen kapasitas 5-ton yang mengalami kegagalan dan telah dilakukan uji komposisi material rear axle shaft tersebut. Berikut adalah tabel hasil uji komposisi material tersbut:

Tabel 1 Hasil Uji Komposisi Material

\begin{tabular}{|l|c|r|r|r|r|r|}
\hline Bahan & $\mathrm{C} \%$ & $\mathrm{Mn} \%$ & $\mathrm{Si} \%$ & $\mathrm{~S} \%$ & $\mathrm{Cr} \%$ & $\mathrm{Ni} \%$ \\
\hline $\begin{array}{l}\text { Limbah } \\
\text { rear axle } \\
\text { shaft }\end{array}$ & 0,45 & 0,5 & 0,1 & 0,00 & 0,34 & 0,02 \\
\hline
\end{tabular}

Dari data terebut menunjukan bahwa objek penelitian yang berupa limbah rear axle shaft merupakan baja karbon medium. Setelah itu akan dilakukan penyambungan material menggunakan friction welding dengan spesimen yang telah disesuaikan mendekati ukuran specimen uji impact.

Variabel yang digunakan pada penelitian ini antara lain: Variabel Bebas

- Kecepatan putar spindle mesin bubut dengan kecepatan 1010 rpm dam $1800 \mathrm{rpm}$

- Tekanan aksial pada fase penempaan sebesar 20 $\mathrm{Kg} / \mathrm{cm}^{2}, 30 \mathrm{Kg} / \mathrm{cm}^{2}$ dan $40 \mathrm{Kg} / \mathrm{cm}^{2}$

Variabel Kontrol

- Operator

- Material (kandungan kimia, ukuran)

- Mesin - mesin yang digunakan

- Waktu dan tekanan pada fase tekanan gesek

- Suhu ruangan

Variabel terikat

- Nilai Ketangguhan bahan

\section{Proses pengelasan}

\section{HASIL DAN DISKUSI}

Pada proses pengelasan gesek (friction welding) waktu gesekan dipengaruhi kecepatan putar sehingga dapat mempengaruhi temperatur pada proses gesekan. Temperatur gesekan ini dapat mempengaruhi kekuatan impact spesimen 
hasil pengelasan hal ini disebabkan karena temperatur berpengaruh terhadap perubahan struktur mikro hasil pengelasan tersebut. Selain temperatur gesekan waktu pendinginan juga berpengaruh terhadap struktur mikro pada daerah pengelasan. Pada penelitian ini proses pendinginan di lakukan dengan media udara terbuka. Pada penelitian ini didapatkan data proses pengelasan sebagai berikut :

Tabel 2 Data Hasil Pengelasan

\begin{tabular}{|c|c|c|c|c|c|}
\hline $\begin{array}{c}\text { Kecepatan } \\
\text { putaran } \\
(\mathrm{rpm})\end{array}$ & $\begin{array}{c}\text { Tekanan } \\
\text { gesek } \\
\left(\mathrm{Kg} / \mathrm{cm}^{2}\right)\end{array}$ & $\begin{array}{c}\text { Tekanan } \\
\text { tempa } \\
\left(\mathrm{Kg} / \mathrm{cm}^{2}\right)\end{array}$ & $\begin{array}{c}\text { Temp tek } \\
\text { gesek }\left({ }^{\circ} \mathrm{C}\right)\end{array}$ & $\begin{array}{c}\text { waktu } \\
\text { pemanasan } \\
(\mathrm{Sec})\end{array}$ & $\begin{array}{c}\text { waktu } \\
\text { pendinginan } \\
(\mathrm{Sec})\end{array}$ \\
\hline \multirow{3}{*}{1010} & 10 & 20 & 904.9 & 18 & 1500 \\
\cline { 2 - 6 } & 10 & 30 & 932.5 & 18 & 1440 \\
\cline { 2 - 6 } & 10 & 40 & 918.0 & 18 & 1320 \\
\hline \multirow{3}{*}{1800} & 10 & 20 & 1239.0 & 18 & 2160 \\
\cline { 2 - 6 } & 10 & 30 & 1202.4 & 18 & 2040 \\
\cline { 2 - 6 } & 10 & 40 & 1224.0 & 18 & 1980 \\
\hline
\end{tabular}

\section{Pengujian impact}

Pengujian impact dilakukan di laboratorium pengujian bahan Universitas Brawijaya pada tanggal 8 November 2019. Pengujian dilakukan pada 39 spesimen uji pada 3 daerah pengelasan yaitu weld metal, base metal dan heat effected zone.. berikut tabel data hasil uji impact :

Tabel 3 Data Hasil Uji Impact Base Metal

\begin{tabular}{|c|c|c|c|}
\hline Benda uji & Spesimen & $\begin{array}{c}\text { Ketangguhan } \\
\left(\mathrm{J} / \mathrm{mm}^{2}\right)\end{array}$ & $\begin{array}{c}\text { Rata rata } \\
\left(\mathrm{J} / \mathrm{mm}^{2}\right)\end{array}$ \\
\hline Base Metal & BM 1 & 0.044860 & \multirow{2}{*}{0.045140} \\
\hline Base Metal & BM 2 & 0.045380 & \\
\hline Base Metal & BM 3 & 0.045180 & \\
\hline
\end{tabular}

Tabel 4 Data Hasil Uji Impact Kecepatan 1010 Rpm

\begin{tabular}{|c|c|c|c|c|c|}
\hline $\begin{array}{c}\text { Kecepatan } \\
\text { putaran } \\
\text { (rpm) }\end{array}$ & $\begin{array}{c}\text { Tekanan } \\
\text { tempa } \\
\left(\mathrm{Kg} / \mathrm{cm}^{2}\right)\end{array}$ & Daerah & Spesimen & $\begin{array}{c}\text { Ketangguhan } \\
\left(\mathrm{J} / \mathrm{mm}^{2}\right)\end{array}$ & $\begin{array}{c}\text { Rata-Rata } \\
\left(\mathrm{J} / \mathrm{mm}^{2}\right)\end{array}$ \\
\hline \multirow{18}{*}{1010} & \multirow{6}{*}{20} & \multirow{3}{*}{ WM } & A20 1 & 0.048430 & \multirow{3}{*}{0.050613} \\
\hline & & & A20 2 & 0.050760 & \\
\hline & & & A20 3 & 0.052650 & \\
\hline & & \multirow{3}{*}{ HAZ } & A20 4 & 0.046240 & \multirow{3}{*}{0.048070} \\
\hline & & & A20 5 & 0.047240 & \\
\hline & & & A20 6 & 0.050730 & \\
\hline & \multirow{6}{*}{30} & \multirow{3}{*}{ WM } & A30 1 & 0.060430 & \multirow{3}{*}{0.056430} \\
\hline & & & A30 2 & 0.054800 & \\
\hline & & & A30 3 & 0.054060 & \\
\hline & & \multirow{3}{*}{ HAZ } & $\mathrm{A} 304$ & 0.045230 & \multirow{3}{*}{0.044510} \\
\hline & & & A30 5 & 0.045540 & \\
\hline & & & A306 & 0.042760 & \\
\hline & \multirow{6}{*}{40} & \multirow{3}{*}{ WM } & A40 1 & 0.070320 & \multirow{3}{*}{0.065030} \\
\hline & & & A40 2 & 0.064210 & \\
\hline & & & A40 3 & 0.060560 & \\
\hline & & \multirow{3}{*}{ HAZ } & A40 4 & 0.045380 & \multirow{3}{*}{0.045263} \\
\hline & & & A40 5 & 0.046290 & \\
\hline & & & A40 6 & 0.044120 & \\
\hline
\end{tabular}

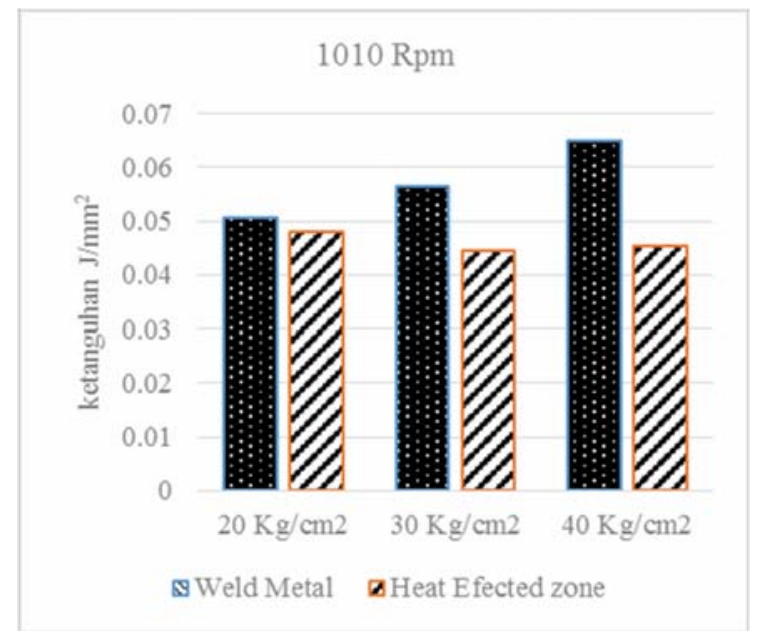

Gambar 2. Grafik Rata-Rata Hasil Uji Impact Pada Variasi Kecepatan Putar 1010 Rpm

Berdasarkan Gambar 2. Menunjukan grafik rata-rata hasil pengujian impact yang diperoleh dari kombinasi kecepatan putar $1010 \mathrm{Rpm}$ dan tekanan tempa $20 \mathrm{Kg} / \mathrm{cm}^{2}, 30 \mathrm{Kg} / \mathrm{cm}^{2}$ dan $40 \mathrm{Kg} / \mathrm{cm}^{2}$ pada posisi Weld Metal dan Heat Effected Zone. Nilai tertinggi pada posisi Weld Metal dimiliki pada spesimen dengan kombinasi kecepatan putar 1010 Rpm dan tekanan tempa $40 \mathrm{Kg} / \mathrm{cm}^{2}$ dengan nilai $0.065030 \mathrm{~J} / \mathrm{mm}^{2}$ dan nilai terendah pada kombinasi kecpetan putar $1010 \mathrm{Rpm}$ dan tekanan tempa $20 \mathrm{Kg} / \mathrm{cm}^{2}$ dengan nilai $0.050613 \mathrm{~J} / \mathrm{mm}^{2}$. Sedangkan pada posisi Heat effected zone, nilai tertinggi dimiliki kombinasi kecepatan putar $1010 \mathrm{Rpm}$ dan tekanan tempa $20 \mathrm{Kg} / \mathrm{cm}^{2}$ dengan nilai $0.048070 \mathrm{~J} / \mathrm{mm}^{2}$ dan nilai terendah pada kombinasi kecpetan putar $1010 \mathrm{Rpm}$ dan tekanan tempa $30 \mathrm{Kg} / \mathrm{cm}^{2}$ dengan nilai $0.044510 \mathrm{~J} / \mathrm{mm}^{2}$

Tabel 5 Data Hasi Uji Impact Kecepatan 1800 Rpm

\begin{tabular}{|c|c|c|c|c|c|}
\hline $\begin{array}{c}\text { Kecepatan } \\
\text { putaran } \\
\text { (rpm) }\end{array}$ & $\begin{array}{c}\text { Tekanan } \\
\text { tempa } \\
\left(\mathrm{Kg} / \mathrm{cm}^{2}\right)\end{array}$ & Daerah & Spesimen & $\begin{array}{c}\text { Ketangguhan } \\
\left(\mathrm{J} / \mathrm{mm}^{2}\right)\end{array}$ & $\begin{array}{c}\text { Rata-Rata } \\
\left(\mathrm{J} / \mathrm{mm}^{2}\right)\end{array}$ \\
\hline \multirow{18}{*}{1800} & \multirow{6}{*}{20} & \multirow{3}{*}{ WM } & B20 1 & 0.043240 & \multirow{3}{*}{0.040970} \\
\hline & & & B20 2 & 0.040240 & \\
\hline & & & B20 3 & 0.039430 & \\
\hline & & \multirow{3}{*}{ HAZ } & B20 4 & 0.044670 & \multirow{3}{*}{0.044703} \\
\hline & & & B20 5 & 0.046860 & \\
\hline & & & B20 6 & 0.042580 & \\
\hline & \multirow{6}{*}{30} & \multirow{3}{*}{ WM } & B30 1 & 0.054150 & \multirow{3}{*}{0.046720} \\
\hline & & & B30 2 & 0.040450 & \\
\hline & & & B30 3 & 0.045560 & \\
\hline & & \multirow{3}{*}{ HAZ } & B30 4 & 0.042280 & \multirow{3}{*}{0.043073} \\
\hline & & & B30 5 & 0.042180 & \\
\hline & & & B30 6 & 0.044760 & \\
\hline & \multirow{6}{*}{40} & \multirow{3}{*}{ WM } & B40 1 & 0.052320 & \multirow{3}{*}{0.050253} \\
\hline & & & B40 2 & 0.050340 & \\
\hline & & & B40 3 & 0.048100 & \\
\hline & & \multirow{3}{*}{ HAZ } & B40 4 & 0.040250 & \multirow{3}{*}{0.040067} \\
\hline & & & B40 5 & 0.042300 & \\
\hline & & & B40 6 & 0.037650 & \\
\hline
\end{tabular}




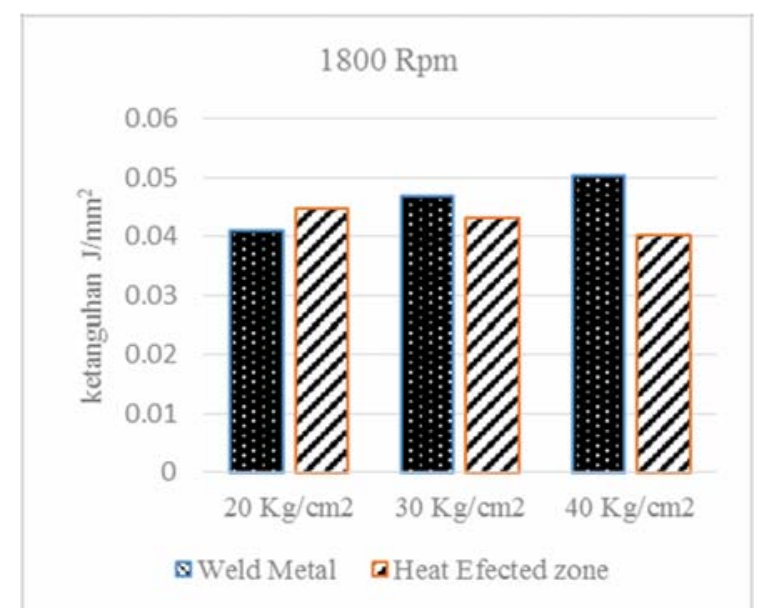

Gambar 3. Grafik Rata-Rata Hasil Uji Impact Pada Variasi Kecepatan Putar 1800 Rpm

Berdasarkan Gambar 3. Menunjukan hasil pengujian impact yang diperoleh dari kombinasi kecepatan putar $1800 \mathrm{Rpm}$ dan tekanan tempa $20 \mathrm{Kg} / \mathrm{cm}^{2}, 30 \mathrm{Kg} / \mathrm{cm}^{2}$ dan $40 \mathrm{Kg} / \mathrm{cm}^{2}$ pada posisi Weld Metal dan Heat Effected Zone. Nilai tertinggi dimiliki pada spesimen dengan kombinasi kecepatan putar $1800 \mathrm{Rpm}$ dan tekanan tempa $40 \mathrm{Kg} / \mathrm{cm}^{2}$ dengan nilai $0.050253 \mathrm{~J} / \mathrm{mm}^{2}$ dan nilai terendah pada kombinasi kecpetan putar $1010 \mathrm{Rpm}$ dan tekanan tempa $20 \mathrm{Kg} / \mathrm{cm}^{2}$ dengan nilai $0.040970 \mathrm{~J} / \mathrm{mm}^{2}$. Sedangkan pada posisi Heat effected zone, nilai tertinggi dimiliki kombinasi kecepatan putar $1010 \mathrm{Rpm}$ dan tekanan tempa $20 \mathrm{Kg} / \mathrm{cm}^{2}$ dengan nilai $0.044703 \mathrm{~J} / \mathrm{mm}^{2}$ dan nilai terendah pada kombinasi kecpetan putar $1010 \mathrm{Rpm}$ dan tekanan tempa $20 \mathrm{Kg} / \mathrm{cm}^{2}$ dengan nilai $0.040067 \mathrm{~J} / \mathrm{mm}^{2}$

\section{Pengujian statistika}

Pada penelitian kali ini teknik analisis data yang digunakan adalah teknik analisis data deskriptif kuantitatif dimana salah dalam teknik ini peneliti akan memperkirakan atau dengan menentukan besarnya pengaruh secara kuantitatif Hasan (2015; 35). Untuk membantu memperkirakan dan menentukan besarnya pengaruh dari hasil penelitian ini kami menggunakan aplikasi SPSS 25 dalam apalikasi ini data akan dia analisis menggunakan metode Anova tunggal (One-Way Anova). Sebelum dilakukan pengujian anova, data harus terlebih dahulu dipastikan bahwa data dari masing-masing variasi berdistribusi normal, sama (homogen), dan sampel tidak berhubungan satu dengan yang lain (tidak homogen). Oleh karena, itu perlu dilakukan uji normalitas dan uji homogenitas terlebih dahulu

\section{a) Uji normalitas}

Berikut hasil uji normalitas data penelitian ini dapat dilihat pada tabel dibawah
Tabel 6 Hasil Uji Normalitas Uji impact WM

\begin{tabular}{|c|c|c|c|c|c|c|c|}
\hline & \multirow{2}{*}{$\begin{array}{r}\text { Kecepatan } \\
\text { Kekuatan } \\
\end{array}$} & \multicolumn{3}{|c|}{$\begin{array}{c}\text { Kolmogorov- } \\
\text { Smirnov }^{\mathrm{a}}\end{array}$} & \multicolumn{3}{|c|}{ Shapiro-Wilk } \\
\hline & & Statistic & df & Sig. & tatistic df & & Sig. \\
\hline \multirow[t]{6}{*}{ WM } & 1010_20 & .194 & 3 & & .996 & 3 & .885 \\
\hline & 1010_30 & .347 & 3 & & .836 & 3 & .203 \\
\hline & 1010_40 & .233 & 3 & & .979 & 3 & .724 \\
\hline & 1800_20 & .309 & 3 & & .901 & 3 & .388 \\
\hline & 1800_30 & .233 & 3 & & .979 & 3 & .722 \\
\hline & $1800 \quad 40$ & .183 & 3 & & 999 & 3 & .932 \\
\hline
\end{tabular}

Tabel 7 Hasil Uji Normalitas Uji impact HAZ

\begin{tabular}{|c|c|c|c|c|c|c|c|}
\hline & \multirow[t]{2}{*}{ Kecepatan_n } & \multicolumn{3}{|c|}{$\begin{array}{c}\text { Kolmogorov- } \\
\text { Smirnov }^{\mathrm{a}}\end{array}$} & \multicolumn{3}{|c|}{ Shapiro-Wilk } \\
\hline & & Statistic & & & Statistic d & & Sig. \\
\hline \multirow[t]{6}{*}{$\mathrm{HZ}$} & $1010 \_20$ & .304 & 3 & & .907 & 3 & .408 \\
\hline & $1010 \_30$ & .348 & 3 & & .832 & 3 & .195 \\
\hline & $1010 \_40$ & .209 & 3 & & .991 & 3 & .823 \\
\hline & 1800_20 & .177 & 3 & & 1.000 & 3 & .974 \\
\hline & $1800 \_30$ & .373 & 3 & & .779 & 3 & .065 \\
\hline & $1800 \quad 40$ & .198 & 3 & & .995 & 3 & .870 \\
\hline
\end{tabular}

Dari hasil uji normalitas diatas dapat diketahui apakah masing-masing variabel terdistribusi normal atau tidak.

Pedoman pengambilan keputusan adalah sebagai berikut:

1. Jika nilai sig. kurang dari 0,05 maka, data dinyatakan memiliki distribusi tidak normal.

2. Jika nilai sig. lebih dari 0,05 maka, data dinyatakan memiliki distribusi normal.

Pedoman ini mengacu pada hasil perhitungan alat $u j i$ normalitas Shapiro-Wilk. Dimana, menurut hasil pengujian didapatkan variabel memiliki nilai sig. diatas 0,05 sehingga dapat dikatakan bahwa data hasil pengujian impact terdistribusi normal. Selanjutnya yang dilakukan adalah uji homogenitas. b) Uji homogenitas

berikut hasil uji homogenitas dapat dilihat pada tabel dibawah 
Table 8 Hasil Uji homogenitas hasil Uji impact HAZ $\mathrm{HZ}$

\begin{tabular}{|c|c|c|l|}
\hline Levene Statistic & \multicolumn{1}{|l|}{$\mathrm{df1}$} & \multicolumn{1}{l|}{$\mathrm{df2}$} & Sig. \\
\hline .519 & 5 & 12 & .757 \\
\hline
\end{tabular}

Tabel 9 Hasil Uji homogenitas hasil Uji impact WM WM

\begin{tabular}{|c|c|c|c|}
\hline Levene Statistic & df1 & $\mathrm{df} 2$ & Sig. \\
\hline 1.715 & 5 & 12 & .206 \\
\hline
\end{tabular}

Uji homogenitas dapat digunakan untuk mengetahui apakah sampel homogen atau tidak. Pedoman pengambilan keputusan adalah sebagai berikut :

1. Jika nilai sig. kurang dari 0,05 maka, data dinyatakan tidak homogen.

2. Jika nilai sig. lebih dari 0,05 maka, data dinyatakan homogen.

Hasil pengujian didapatkan nilai sig. sebesar 0,7 dan 0,2 diatas 0,05 sehingga dapat dikatakan bahwa data hasil impact homogen. Selanjutnya di lakukan uji anova

\section{c) Uji anova}

Analisa menggunakan metode anova tunggal harus memiliki hipotesa sebelum dapat menarik sebuah simpulan,Hipotesa yang diajukan adalah

Ho = Tidak ada pengaruh yang signifikan antara kecepatan putar $1010 \mathrm{Rpm}, 1800 \mathrm{Rpm}$ dan tekanan $20 \mathrm{Kg} / \mathrm{cm}^{2}, 30 \mathrm{Kg} / \mathrm{cm}^{2}$ dan $40 \mathrm{Kg} / \mathrm{cm}^{2}$ terhadap nilai kekuatan impact /bending spesimen hasil pengelasan gesek

- $\mathbf{H a}=$ Ada pengaruh yang signifikan antara kecepatan putar $1010 \mathrm{Rpm}, 1800 \mathrm{Rpm}$ dan tekanan $20 \mathrm{Kg} / \mathrm{cm}^{2}$, $30 \mathrm{Kg} / \mathrm{cm}^{2}$ dan $40 \mathrm{Kg} / \mathrm{cm}^{2}$ terhadap nilai kekuatan impact /bending spesimen hasil pengelasan gesek WM

Table 10 Hasil Uji Anova hasil Uji impact WM

\begin{tabular}{|l|l|l|l|l|l|}
\hline & \multicolumn{1}{|c|}{$\begin{array}{c}\text { Sum of } \\
\text { Squares }\end{array}$} & df & $\begin{array}{c}\text { Mean } \\
\text { Square }\end{array}$ & F & Sig. \\
\hline $\begin{array}{l}\text { Between } \\
\text { Groups } \\
\text { Within } \\
\text { Groups } \\
\text { Total }\end{array}$ & 1029.790 & 5 & 205.958 & 12.695 & .008 \\
\hline
\end{tabular}

Table 11 Hasil Uji Anova hasil Uji impact HAZ $\mathrm{HZ}$

\begin{tabular}{|l|c|c|c|c|c|}
\hline & $\begin{array}{c}\text { Sum of } \\
\text { Squares }\end{array}$ & df & $\begin{array}{c}\text { Mean } \\
\text { Square }\end{array}$ & F & Sig. \\
\hline Between & 104.314 & 5 & 20.863 & 5.901 & .006 \\
$\begin{array}{l}\text { Groups } \\
\text { Within } \\
\text { Groups } \\
\text { Total }\end{array}$ & 42.425 & 12 & 3.535 & & \\
\hline
\end{tabular}

Dasar pengambilan keputusan anova tunggal adalah perbandingan $\mathrm{F}$ hitung dengan $\mathrm{F}$ tabel. Dengan ketentuan sebagai berikut:

Jika F hitung (angka F output $>$ statistik tabel (tabel F), maka Ho ditolak,Ha diterima

Jika F hitung (angka F output < statistik tabel (tabel F), maka Ho diterima,Ha ditolak

Nilai F hitung pada tabel 4.9 adalah 12.695, tabel 4.10 adalah 5.901 untuk uji impact dan table 4.11 adalah 86.908 dengan nilai signifikansi 0,05 sementara nilai statistik tabel dapat ditemukan pada tabel $\mathrm{F}$, dalam uji anova ini menggunakan tingkat signifikansi $(\alpha)$ sebesar 5\%. Untuk menentukan $\mathrm{F}$ tabel dibutuhkan $\mathrm{dk}$ pembilang dan $\mathrm{dk}$ penyebut, $\mathrm{dk}$ pembilang dengan menghitung didapatkan jumlah variabel kelompok dikurangi 1 maka 6-1 =5; sedangkan $\mathrm{dk}$ penyebut adalah jumlah seluruh sampel dikurangi jumlah variabel kelompok maka 15-3=12 dengan nilai dk pembilang 2 dan dk penyebut 12 maka didapatkan nilai $F$ tabel 4.5 adalah 3.11 untuk uji impact.

Berdasarkan uraian diatas pada uji impact nilai $\mathrm{F}$ hitung lebih besar daripada nilai $\mathrm{F}$ tabel 4.18 yakni sebesar 12.695> 3.11 dan nilai $\mathrm{F}$ pada Tabel 4.19 yakni sebesar $5.901>3.11$. Maka dapat disimpulkan bahwa Ha diterima dan Ho ditolak atau dengan kata lain ada pengaruh yang signifikan antara kecepatan putar $1010 \mathrm{Rpm}, 1800 \mathrm{Rpm}$ dan tekanan $20 \mathrm{Kg} / \mathrm{cm}^{2}$, $30 \mathrm{Kg} / \mathrm{cm}^{2}$ dan $40 \mathrm{Kg} / \mathrm{cm}^{2}$ terhadap nilai kekuatan impact /bending spesimen hasil pengelasan gesek

\section{Analisa kekuatan impact terhadap tekanan tempa pada kecepatan putar (rotational speed) $1010 \mathrm{Rpm}$ dan 1800 Rpm}

Dari data hasil Pengujian Impact pada tabel 4.2 dibuat grafik hubungan antara tekanan tempa dengan kekuatan Impact (Impact Strength) di daerah WM maupun di HAZ pada masing masing kecepatan yang dapat dilihat pada gambar grafik dibawah ini

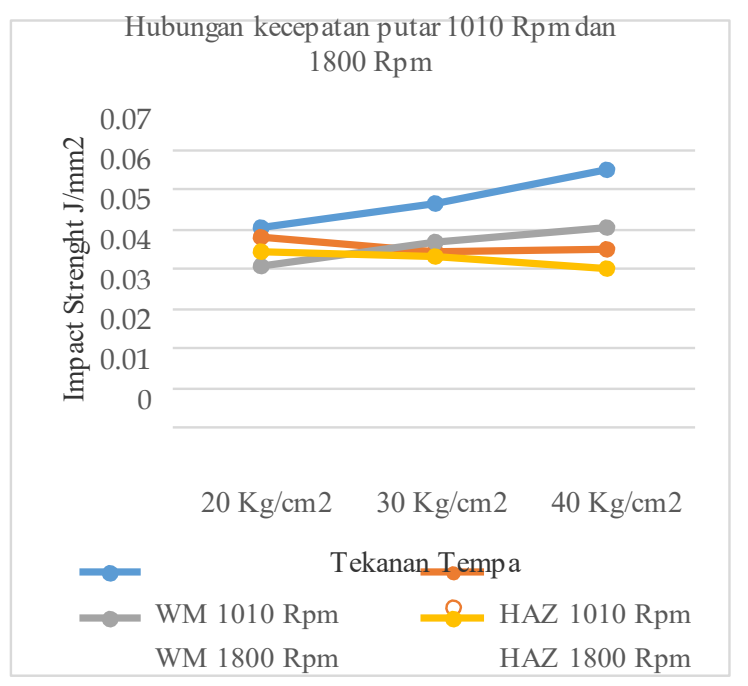

Gambar 4 Grafik Hubungan Kecepatan Putar Dan Tekanan Tempa Hasil Pengujian Impact 
Berdasarkan gambar 4, dapat dilihat pada grafik dengan variasi kecepatan putar (rotational speed) $1010 \mathrm{Rpm}$ dan 1800 Rpm yang menunjukan bahwa tekanan tempa mempengaruhi kekuatan impact, semakin tinggi tekanan tempa yang diberikan maka kekuatan impact nya semakin tinggi pula. Itu dibuktikan dengan nilai kekuatan impact pada variasi kecepatan $1010 \mathrm{Rpm}$ paling rendah pada tekanan tempa 20 $\mathrm{Kg} / \mathrm{cm}^{2}$ diperoleh kekuatan impact sebesar $0.050613 \mathrm{~J} / \mathrm{mm}^{2}$ dan kekuatan impact paling tinggi pada tekanan tempa 40 $\mathrm{Kg} / \mathrm{cm}^{2}$ diperoleh kekuatan impact sebesar $0.065030 \mathrm{~J} / \mathrm{mm}^{2}$. Hal ini juga terjadi dengan nilai kekuatan impact pada variasi kecepatan $1800 \mathrm{Rpm}$ dengan nilai kekuatan impact paling rendah pada tekanan tempa $20 \mathrm{Kg} / \mathrm{cm}^{2}$ diperoleh kekuatan impact sebesar $0.04097 \mathrm{~J} / \mathrm{mm}^{2}$ dan kekuatan impact paling tinggi pada tekanan tempa $40 \mathrm{Kg} / \mathrm{cm}^{2}$ diperoleh kekuatan impact sebesar $0.050253 \mathrm{~J} / \mathrm{mm}^{2}$ serta bentuk grafik yang relatif meningkat hal ini disebabkan karena panas yang dihasilkan dari bahan di permukaan benda kerja akan menyebabkan deformasi plastis, panas tersebut dihasilkan oleh gesekan pada fase tekanan gesek tekanan gesek akan membangkitkan temperatur di permukaaan selanjutnya dilakukan tahap penempaan, tekanan penempaan ini dimaksudkan untuk mengurangi void (kontaminan lapisan oksida) yang di hasilkan dari kontak antara yield dan creep. Dilanjutkan dengan difusi vacancy yang menghilangkan lapisan oksida dan beberapa void kecil sehingga semakin tinggi tekanan tempa maka void (lapisan oksida) akan semakin kecil, semakin kecil void maka ikatan difusi antara kedua permukaan spesimen akan lebih baik. Semakin baik ikatan difusi maka semakin tinggi pula nilai ketangguhannya selain itu tekanan tempa akan mengakibatkan pemadatan struktur mikro yang menyebabkan banyak fasa pearlite yang dihasilkan yang menyebabkan peningkatan ketangguhan pada spesimen.

Namun dilihat dari grafik data hasil uji impact di daerah HAZ menunjukan bahwa pada daerah HAZ memiliki nilai impact strange yang lebih rendah dari WM hal ini disebabkan karena material (base metal) memang memiliki rata- rata impact strange yang rendah yaitu $0.045140 \mathrm{~J} / \mathrm{mm}^{2}$. Adapun dari grafik yang menunjukan semakin kecil tekanan tempa maka akan semakin tinggi impact strange di daerah HAZ dapat dilihat dari grafik nilai impact strange kecepatan 1010 Rpm yang paling tinggi justru berada pada spesimen dengan variasi tekanan yang paling rendah $20 \mathrm{Kg} / \mathrm{cm}^{2}$ yaitu 0.048070 $\mathrm{J} / \mathrm{mm}^{2}$ dan impact strange yang paling rendah pada spesimen dengan tekanan tempa $30 \mathrm{Kg} / \mathrm{cm}^{2}$ yaitu $0.044510 \mathrm{~J} / \mathrm{mm}^{2}$ dan memiliki grafik yang relative menurun. Hal ini juga terjadi pada kecepatan putar 1800 Rpm dengan nilai impact strange yang paling tinggi justru berada pada spesimen dengan variasi tekanan yang paling rendah $20 \mathrm{Kg} / \mathrm{cm}^{2}$ yaitu $0.044703 \mathrm{~J} / \mathrm{mm}^{2}$ bahkan lebih tinggi dibandingkan dengan hasil uji impact di daerah WM dan yang paling rendah pada spesimen dengan tekanan tempa $40 \mathrm{Kg} / \mathrm{cm}^{2}$ yaitu $0.040067 \mathrm{~J} / \mathrm{mm}^{2}$ dan memiliki grafik yang relative menurun. Hal ini disebabkan karena pengaruh temperatur di daerah pengelasan yang mencapai $1221^{\circ} \mathrm{C}$ dan $918^{\circ} \mathrm{C}$ sehingga memiliki waktu pendinginan yang berbeda sehingga akan mempengaruhi daerah HAZ.
Selain itu hasil uji impact pada spesimen dengan variasi kecepatan 1010 Rpm memiliki kekuatan impact lebih tinggi di bandingkan dengan dengan spesimen dengan variasi kecepatan $1800 \mathrm{Rpm}$. Hal ini disebabkan karena pada proses pengelasan gesek ini memiliki momen inersia, kecepatan putaran akan meningkatkan kecepatan pembangkitan temperatur di permukaan pada tahap tekanan gesek, sedangkan pada proses pengelasan kecepatan putar akan tetap konstan. Hal ini menunjukan bahwa kecepatan putaran mempengaruhi cepat lambatnya temperatur yang dibangkitkan, namun semakin tinggi kecepatan putaran maka momen inersia yang dihasilkan juga semakin besar sehingga membutuhkan gaya pengereman yang semakin besar juga. Semakin besar gaya yang di butuhkan untuk fase pengereman maka akan mempengaruhi proses ikatan difusi kedua spesimen

\section{Analisa Proses Pengelasan Berdasarkan Temperatur Dan Waktu}

Pada proses pengelasan gesek (friction welding) waktu gesekan dipengaruhi kecepatan putar sehingga dapat mempengaruhi temperatur pada proses gesekan. Temperatur gesekan ini dapat mempengaruhi kekuatan bending maupun kekuatan impact spesimen hasil pengelasan hal ini disebabkan karena temperatur berpengaruh terhadap struktur mikro hasil pengelasan tersebut. Selain temperatur gesekan waktu pendinginan juga berpengaruh terhadap struktur mikro pada daerah pengelasan. Dari penelitian proses pendinginan di lakukan dengan media udara terbuka.

Dapat dilihat dari data table 4.1 menunjukan bahwa pada kecepatan putar 1010 Rpm dalam waktu 18 detik rata- rata temperatur pada daerah pengelasan mencapai $918^{\circ} \mathrm{C}$ dan pada variasi kecepatan putar $1800 \mathrm{Rpm}$ dalam waktu 18 detik ratarata temperatur pada daerah pengelasan mencapai $1221^{\circ} \mathrm{C}$. dilihat dari Diagram Kesetimbangan Fasa Fe-Fe3c dibawah

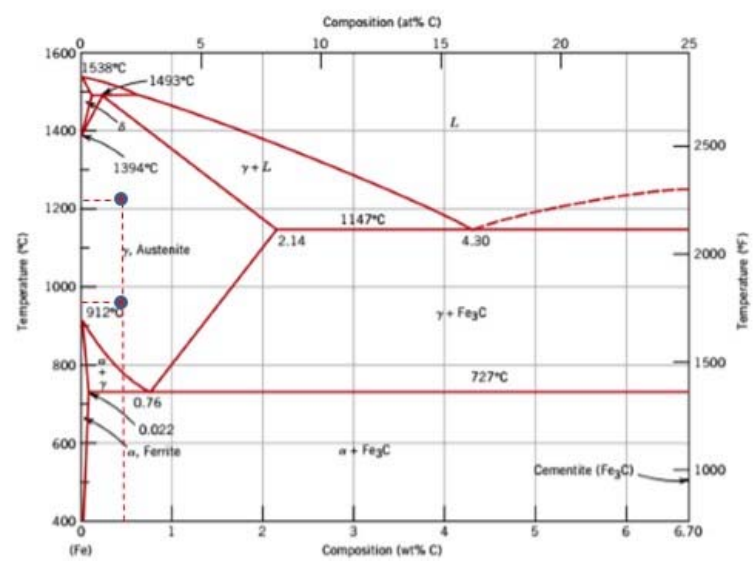

Gambar 5 Diagram Kesetimbangan Fasa Fe-Fe3c

Dari Diagram Kesetimbangan Fasa $\mathrm{Fe}-\mathrm{Fe} 3 \mathrm{c}$ di atas menujukan bahwa temperatur pada daerah pengelasan terdapat pada daerah fasa austenite ditentukan dari komposisi material yang merupakan carbon medium dengan kadar $\mathrm{C}$ (carbon) yaitu $0,45 \%$ dan temperatur rata rata pada daerah pengelasan yang mencapai $918^{\circ} \mathrm{C}$ dan $1221^{\circ} \mathrm{C}$ dimana daerah fasa 
austenite terletak diatas temperatur kritis (A1)yaitu $723^{\circ} \mathrm{C}$ sehingga dapat dipastikan pada daerah pengelasan telah mengalami perubahan struktur. Fasa austenite merupakan fasa sangat kritis dalam menetukan hasil akhir kekuatan mekanik suatu material berdasarkan struktur mikro. untuk mengetahui hasil akhir kekutan mekanik material dapat dilihat melalui perubahan struktur mikro material yang dapat dilihat melalui diagram CCT di bawah:

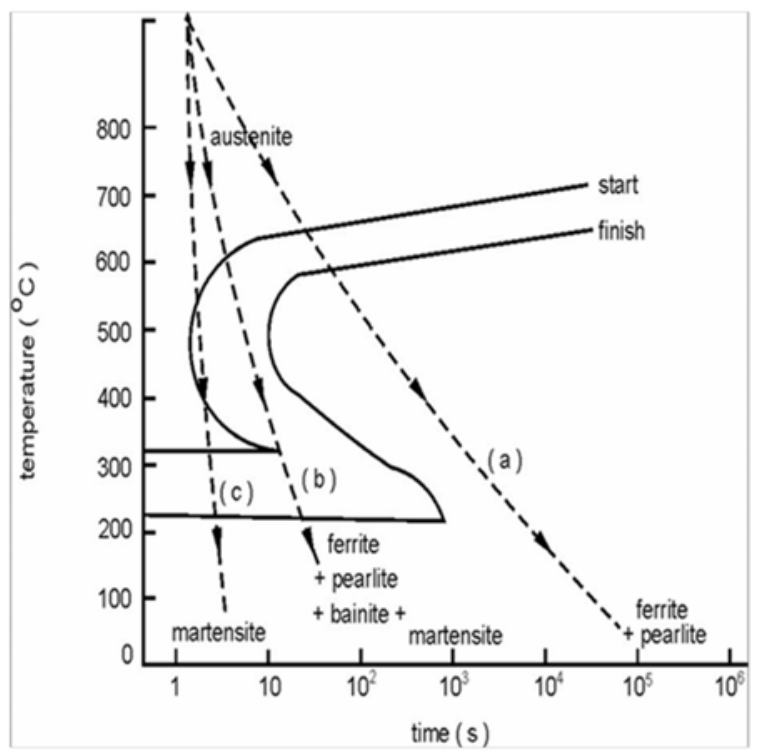

Gambar 6 Diagram CCT

Dari diagram CCT di atas menunjukan bahwa proses pendinginan pada proses pengelasan ini memiliki kurva pendinginan dengan laju pendinginan sedang /medium dilihat dari waktu pendinginan dari suhu awal hingga $100^{\circ} \mathrm{C}$ material yaitu $1500 \mathrm{Sec}, 1440 \mathrm{Sec}, 1320 \mathrm{Sec}, 2160 \mathrm{Sec}, 2040 \mathrm{Sec}$, 1980 Sec. Dengan laju pendinginan kontinyu ini fasa austenite terdekomposisi menjadi struktur ferrite, pearlite, dan terdapat sedikit martensit dan bainite . hal ini di perkuat dengan hasil foto mikro dibawah :



Gambar 7 Foto Struktur Mikro Daerah Weld Metal
Dari hasil foto mikro terlihat fasa ferit, fasa perlit dan sedikit fasa martensit. Fasa ferit ditunjukkan dengan warna cerah sedangkan fasa perlit menunjukkan gambar yang berwarna gelap dan sedikit fasa martensit yang berwarna gelap yang mengumpul. Dilihat dari struktur mikro menunjukan bahwa hasil spesimen pengelasan pada daerah weldmetal memiliki kekuatan mekanik yang relativ ulet karena fasa ferit dan martensit lebih dominan di bandingkan fasa martensit

\section{Analisa patahan hasil uji impact}

Dari hasil pengujian impact selain data kekutan impact (impact strange) patahan spesimen juga digunakan untuk menganalisa hasil lasan spesimen. Dimana dari hasil analisa menggunakan foto makro dengan perbesaran 36X memperlihatkan hasil patahan dimana secara umum terdapat 2 jenis patahan yang terjadi pada spesimen uji impact yaitu Brittle-to-ductile transition dan brittle, berikut hasil analisis dengan jenis patahan Brittle-to-ductile transition dengan gambar di bawah ini



Gambar 8 Brittle-to-ductile transition

Gambar diatas menunjukan patahan transisisi antara getas (brittle) menuju ke jenis patahan ulet (ductile) hal ini di lihat dari gambar permukaan patahan yang relative ini tampak berserat (atau karakter geser), terjadi necking yang mengarah ke ulet namun patah mepunyai tekstur granular (mengkilap) yang cenderung mengarah ke patah getas. Sehingga dapat di klasifikasikan pada jenis patah transisi

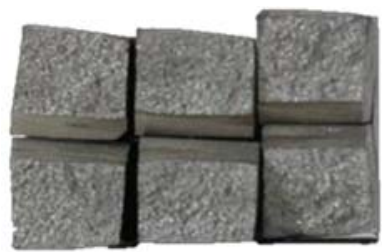

Gambar 9 brittle

Gambar diatas menunjukan patahan getas (brittle) hal ini di lihat dari gambar permukaan patahan yang relative ini mepunyai tekstur granular (mengkilap) dan atau karakter pembelahan yang cenderung mengarah ke patah getas. Sehingga dapat di klsifikasikan pada jenis patah getas (brittle)

KESIMPULAN

Berdasarkan hasil penelitian dan pembahasan, Pengaruh kecepatan putar (rotational speed) $1010 \mathrm{Rpm}$ dan $1800 \mathrm{Rpm}$ dengan tekanan tempa $20 \mathrm{Kg} / \mathrm{cm}^{2}, 30 \mathrm{Kg} / \mathrm{cm}^{2}$ dan $40 \mathrm{Kg} / \mathrm{cm}^{2}$ maka dapat di simpulkan sebagai berikut:

1. Kecepatan putar (rotational speed) berpengaruh terhadap kekuatan impact hasil pengelasan gesek. Dimana

kekuatan impact terbesar terdapat pada variasi kecepatan putar 1010 Rpm dengan hasil kekuatan impact 0.065030 
$\mathrm{J} / \mathrm{mm}^{2}$ pada daerah weld metal sedangkan hasil uji impact terendah pada daerah weld metal di hasilkan dari variasi kecepatan putar $1800 \mathrm{Rpm}$ yaitu $0.040970 \mathrm{~J} / \mathrm{mm}^{2}$ pada tekanan tempa $20 \mathrm{Kg} / \mathrm{cm}^{2}$ untuk uji impact. Sedangkan pada daerah Heat Efected Zone kekuatan terbesar terdapat pada variasi kecepatan putar $1010 \mathrm{Rpm}$ dengan tekanan $20 \mathrm{Kg} / \mathrm{cm}^{2}$ yaitu $0.048070 \mathrm{~J} / \mathrm{mm}^{2}$ dan terendah pada variasi $1800 \mathrm{Rpm}$ dengan tekanan $40 \mathrm{Kg} / \mathrm{cm}^{2}$ dengan nilai 0.04097 $\mathrm{J} / \mathrm{mm}^{2}$

2. Tekanan tempa (axial force) berpengaruh terhadap kekuatan impact hasil pengelasan gesek. Dimana kekuatan impact terbesar terdapat pada variasi tekanan tempa $40 \mathrm{Kg} / \mathrm{cm}^{2}$ dengan hasil tertinggi $0.065030 \mathrm{~J} / \mathrm{mm}^{2}$ pada daerah weld metal. sedangkan hasil uji impact terendah di hasilkan dari pada tekanan tempa $20 \mathrm{Kg} / \mathrm{cm}^{2}$ yaitu $0.040970 \mathrm{~J} / \mathrm{mm}^{2}$ untuk uji impact. Sedangkan pada daerah Heat Efected Zone kekuatan terbesar terdapat pada variasi kecepatan putar $1010 \mathrm{Rpm}$ dengan tekanan 20 $\mathrm{Kg} / \mathrm{cm}^{2}$ yaitu $0.048070 \mathrm{~J} / \mathrm{mm}^{2}$ dan terendah pada variasi $1800 \mathrm{Rpm}$ dengan tekanan $40 \mathrm{Kg} / \mathrm{cm}^{2}$ dengan nilai $0.04097 \mathrm{~J} / \mathrm{mm}^{2}$

\section{REFERENSI}

[1] ANSI/AWS C6.1-89. An American National Standard.2012. Recommended Practices for Friction Welding 1st Edition.

[2] ASTM E23-07a, 1993. Volume 8-Mechanical Testing and Evaluation. UNITED STATES OF AMERICA.

[3] ASM Handbook, 1993. Welding, Brazing and Soldering, UNITED STATES OF AMERICA.

[4] EN Cahyo, S Dimas Angga. 2010. Analisa Pengaruh Waktu Gesekan Terhadap Struktur Mikro dan Sifat Mekanik pada Pipa Baja ASTM A106 dengan Metode Friction Welding. D3 Teknik Mesin, FTI, ITS, Surabaya,

[5] F Fauzi, 2016. Analisis Perancangan Penggerak Belakang Gokart 150cc Dohc.Universitas Muhamadiyah Yogyakarta

[6] Faisal, Dkk,(2018). Analisis Kekuatan Tarik pada Logam Axle Shaft dengan Pengelasan Gesek (Friction Welding). Jurnal teknologi volume 19 Univesitas Muslim Indonesia

[7] Haryanto, poedji, Dkk. 2011. Prosiding Seminar Nasional Sains dan Teknologi ke-2 Tahun 2011 Fakultas Teknik Universitas Wahid Hasyim Semarang. Pengaruh Gaya Tekan, Kecepatan Putar, Dan Waktu Kontak Pada Pengelasan Gesek Baja St60 Terhadap Kualitas Sambungan Las.

[8] Josep Edward Shigley, 1983. Mechanical engineering design. Jakarta: Erlanga.

[9] Sularso, kiyokatsu suga, 1997. Dasar perencanaan dan pemilihan elemen mesin. Jakarta : Pradnya Paramita

[10] M Syahril. 2013. Analisa Kegagalanporos Roda Belakang Kendaraan. balai besar teknologi kekuatan struktur (B2TKS) BPP Teknologi kawasan PUSPITEK tangerang .

[11] Nugroho, wahyu. 2010. Pengaruh durasi gesekan, tekanan gesek dan tekanan tempa terhadap kekuatan sambungan las gesek langsung pada baja karbon aisi 1045. Teknik Mesin, FTI, ITS, Surabaya

[12] Orlando, Noel. 2012. Analisis finite element pada kontruksi poros roda belakang truk fuso ps 500. Universitas Islam Indonesia

[13] Priyanto,Eko.2013. Laporan Praktik Industri, Proses Pembuatan Rear Axle Shaft Di Pt IGP. Universitas Diponegoro

[14] RS Khurmi, JK Gupta. 2005. Theory of machines. S. Chand \& Co.Ltd., New Dehli

[15] Satyadianto, dicky. 2015. Pengaruh Variasi Tekanan Gesek,Tekanan Tempa Dan Durasi Gesek Terhadap Kekuatan
Impact Pada Sambungan Las Gesek (Friction Welding) Dengan Menggunakan Baja Paduan Aisi 4140

[16] Siswanto. 2011. Konsep Dasar Teknik Las (Teori dan Praktik).Jakarta : P.T. Prestasi Pustakarya..

[17] Sugeng, 2013. Pemeliharaan Sasis Dan Sistem Pemindah Tenaga. Direktorat Jendral Mutu Pendidik Dan Tenaga Kependidikan Kementrian Pendidikan Dan Kebudayaan

[18] Sugiyono. 2014. Metodologi penelitian. Bandung, Alfabeta

[19] Wahab, Rifanly Dkk, 2017. Analisis Kelelahan Axle Shaft Truk ISUZU ELF 125 Ps. Jurusan Teknik Mesin Universitas Sam Ratulangi Manado.

[21] Weman, Klas., 2011 , "Welding Process Handbook", Woodhead, Cambride,. England.

[22] Wibowo.2016. Optimalisasi Heat Input Pengelasan Gmaw Baja A36 Melalui Pemeriksaan Hasil Las. Universitas sebelas maret 